\title{
HUBUNGAN SMARTPHONE ADDICTION DENGAN PERAN IBU DALAM MENJALANKAN FUNGSI KELUARGA
}

\author{
Arantika Meidya Pratiwi ${ }^{1}$, Ratih Devi Alfiana ${ }^{2}$ \\ ${ }^{1,2}$ Universitas Alma Ata, arantika.meidya @almaata.ac.id
}

\section{INFORMASI ARTIKEL:}

Riwayat Artikel:

Tanggal di Publikasi: Desember 2020

Kata kunci:

Smartphone addiction

Peran ibu

Fungsi keluarga

\section{A B S T R A K}

Perceraian dalam rumah tangga diawali oleh konflik yang terjadi dalam rumah tangga tersebut. Salah satu masalah dalam terjadinya konflik dikarenakan kurang adanya kontrol emosi dalam penyelesaian masalah suami-istri, dan suami-istri yang terlena dengan aktivitasnya masingmasing. Belakangan ini bukan hanya aktivitas diluar rumah yang memicu konflik dalam rumah tangga, namun juga aktivitas di dalam rumah seperti menggunakan smartphone. Hasil wawancara dengan lima orang suami menyatakan bahwa 3 dari 5 suami menganggap istri mereka terlalu sering menggunakan smartphone saat dirumah. Mereka menyatakan bahwa banyak pekerjaan rumah yang tertunda karena istri mereka bermain smartphone. Dua dari lima suami menyatakan bahwa istri mereka tetap bermain smartphone bahkan saat bermain dengan anaknya. Penelitian ini bertujuan untuk mengetahui hubungan antara smartphone addiction dengan peran ibu dalam menjalankan fungsi keluarga. Penelitian ini menggunakan jenis penelitian observasional analitik dengan pendekatan cross sectional. Populasi dalam penelitian ini adalah wanita yang memiliki anak usia toodler yang bersekolah di PAUD dan sederajat di Kecamatan Kasihan, Bantul, Yogyakarta dan memiliki smartphone. Sampel penelitian ini diambil secara multistage random sampling. Besar sampel yang digunakan dalam penelitian ini sebanyak 104 responden yang terbagi dalam 4 PAUD di 4 Desa yang ada di Kecamatan Kasihan. Hubungan kedua variabel diuji dengan Spearman rank. Hasil analisis korelasi dengan Spearman rank menggunakan SPSS menunjukkan bahwa nilai Koefisien korelasi Spearman Rank (r) sebesar -0,360 dengan nilai signifikansi $0,000(\mathrm{p}<0,05)$ yang menunjukkan bahwa ada hubungan yang negatif dan signifikan (berarti) antara smartphone addiction dengan peran ibu dalam menjalankan fungsi keluarga dengan kekuatan hubungan cukup kuat. 


\section{PENDAHULUAN}

Perceraian menjadi permasalahan yang setiap tahunnya memperlihatkan peningkatan yang signifikan. Angka gugat cerai di Indonesia terus meningkat sepanjang tahun. Kondisi ini merata hampir di semua daerah di Indonesia. Angka perceraian yang terjadi di Indonesia. Berdasarkan data dari Badan Pusat Statistik, pada kasus perceraian tahun 2012 yakni, cerai dan talak sebanyak 346.480 kasus. Di tahun 2013, cerai dan talak sebanyak 324.247 kasus. Di tahun 2014, cerai dan talak sebanyak 344.237 kasus. Di tahun 2015, cerai dan talak sebanyak 347.256 kasus (Badan Pusat Statistik, 2017).

Perceraian dalam rumah tangga diawali oleh konflik yang terjadi dalam rumah tangga tersebut. Salah satu masalah dalam terjadinya konflik dikarenakan kurang adanya kontrol emosi dalam penyelesaian masalah suami-istri, dan suami-istri yang terlena dengan aktivitasnya masing-masing (Dildar, Stwat,\& Yasin, 2013). Belakangan ini bukan hanya aktivitas diluar rumah yang memicu konflik dalam rumah tangga, namun juga aktivitas di dalam rumah seperti menggunakan smartphone.

Menurut survey yang dilakukan oleh Asosiasi Penyelenggara Jaringan Internet Indonesia pada tahun 2016, sebanyak 132,7 juta orang Indonesia telah terhubung ke internet. Hal tersebut mengindikasikan kenaikan jumlah pengguna internet dibandingkan hasil survey pada 2014 lalu. Data survei juga mengungkap bahwa rata-rata pengakses internet di Indonesia menggunakan perangkat genggam, yaitu sebanyak 63,1 juta orang mengakses internet dari smartphone. Survey yang dilakukan
Rapid Value Solution pada tahun 2014 menyatakan bahwa Indonesia berada di peringkat pertama daftar pengguna smartphone terbesar di Asia Tenggara dengan jumlah pengguna mencapai 57,5 juta (Rapid Value Solution, 2014).

Salah satu hasil penelitian menunjukkan bahwa penggunaan smartphone berkaitan dengan kerugian yang didapatkan (Attamimi, 2011). Semakin sering individu menggunakan smartphone, semakin mereka menjadi ketergantungan pada smartphone (Hong, Chiu \& Huang, 2012). Bahkan adanya smartphone juga memiliki efek baru pada perilaku penggunanya (Bian \& Leung, 2014). Kemunculan smartphone membuat seseorang lebih asik dan sibuk dengan fitur yang terdapat pada alat tersebut, mereka jauh lebih menyukai interaksi via jejaring sosial media, daripada bertatap muka langsung. Gejala perilaku tersebut yaitu seseorang jauh lebih peka pada sesuatu yang terjadi dengan smartphone yang dibawa daripada lingkungan sekitarnya, yang kemudian hal tersebut akan menjadi sebuah masalah bagi penggunanya (Salehan \& Neghaban, 2013).

Belakangan ini smartphone addiction tidak hanya terjadi pada remaja, namun juga pada orang dewasa baik yang belum menikah ataupun sudah menikah. Smartphone addiction pada kalangan orang yang sudah menikah dapat memicu konflik dalam rumah tangga karena dapat mengganggu komunikasi intim antara suami dan istri.Hasil wawancara dengan lima orang suami menyatakan bahwa 3 dari 5 suami menganggap istri mereka terlalu sering menggunakan smartphone saat dirumah. Mereka menyatakan bahwa banyak pekerjaan rumah yang tertunda karena istri mereka bermain smartphone. Dua dari lima suami menyatakan bahwa istri 
mereka tetap bermain smartphone bahkan saat bermain dengan anaknya. Dari hasil wawancara tersebut dapat memberikan gambaran bahwa akibat penggunaan smartphone, peran Ibu dalam keluarga mulai tidak maksimal.

\section{METODE PENELITIAN}

Penelitian ini menggunakan jenis penelitian observasional analitik dengan pendekatan cross sectional. Penelitian ini dilaksanakan di kecamatan Kasihan, Bantul, Yogyakarta pada bulan Oktober - Desember 2018. Populasi dalam penelitian ini adalah wanita yang memiliki anak usia toodler yang bersekolah di PAUD dan sederajat di Kecamatan Kasihan, Bantul, Yogyakarta dan memiliki smartphone yaitu sebanyak 1.067 orang. Jumlah sampel penelitian ini sebanyak 104 responden dihitung dengan rumus jumlah minimal sampel dari Slovin. Sampel penelitian ini diambil secara multistage random sampling dari 4 desa di wilayah kecamatan Kasihan meliputi Desa Bangunjiwo, Ngestiharjo, Tamantirto dan Tirtonirmolo. Pemilihan PAUD di setiap desa dilakukan lottery technique, dan pemilihan responden di setiap PAUD juga dilakukan dengan teknik yang sama. Dari hasil pengundian, peneliti mendapatkan 4 PAUD, yaitu SPS Cahaya Hati (Bangunjiwo), KBIT Al Farabi (Tamantirto), KB Qatrunnada (Ngesttiharjo), dan PAUD Terpadu Taat Insan Mulia (Tirtonirmolo). Kriteria eksklusi yang ditetapkan untuk mengurangi bias dalam penelitian ini adalah ibu yang sudah bercerai, ibu yang tinggal terpisah dengan anaknya, dan ibu yang tidak bersedia menjadi responden.
HASIL DAN PEMBAHASAN

Karakteristik Responden

Tabel 1. Tabel Karakteristik Responden

\begin{tabular}{|c|c|c|}
\hline VARIABEL & $f$ & $6 \%$ \\
\hline \multicolumn{3}{|l|}{ OmurIbu } \\
\hline $17-25$ & 14 & 13,5 \\
\hline $26-35$ & 63 & 60.5 \\
\hline $36-45$ & 27 & 26 \\
\hline Jumlah & 104 & 100 \\
\hline \multicolumn{3}{|l|}{ Pendidiksn Teraldir } \\
\hline SNP & 2 & 19 \\
\hline SNAA & 44 & 42,3 \\
\hline D3 & 22 & 21,2 \\
\hline \$1 & 33 & 31,7 \\
\hline Magister & 3 & 29 \\
\hline Jumlah & 104 & 100 \\
\hline \multicolumn{3}{|l|}{ Pelierjagn } \\
\hline$I R T$ & 45 & 433 \\
\hline PNS & 8 & 77 \\
\hline Wirarvasta & 15 & 144 \\
\hline Bayawan Svasta & 36 & 34.6 \\
\hline Junlah & 104 & 100 \\
\hline \multicolumn{3}{|c|}{ Smartphane Adenction } \\
\hline Sangat Rendah & 48 & 462 \\
\hline Rendah & 37 & 355 \\
\hline Sadang & 13 & 125 \\
\hline Iingi & 6 & 58 \\
\hline Sangat Iingei & 0 & 0 \\
\hline Jumlah & 104 & 100 \\
\hline \multicolumn{3}{|l|}{ Peran Ibu } \\
\hline Sangat Bain & 74 & 71,2 \\
\hline Baik & 28 & 26.9 \\
\hline cukup & 2 & 1.9 \\
\hline Eurang & 0 & 0 \\
\hline Sangat kufang & 0 & 0 \\
\hline Jumlah & 104 & 100 \\
\hline
\end{tabular}

Tabel 1 menunjukkan bahwa mayoritas responden berada dalam masa dewasa awal atau usia 26-45 tahun yaitu sebanyak 63 responden $(60,5 \%)$. Sebanyak 27 responden (26\%) berada dalam masa dewasa akhir atau kisaran umur 36-45 tahun dan 14 responden $(13,5 \%)$ berada dalam masa remaja akhir atau kisaran umur 17-25 tahun. Pendidikan terakhir sebagian besar responden adalah SMA yaitu sebanyak 44 responden (42,3\%). Kelompok responden terkecil adalah lulusan SMP dengan 2 orang responden (1,9\%). Mayoritas responden merupakan ibu rumah tangga yakni sebanyak 45 responden (43.3\%). Kelompok responden terkecil bekerja sebagai PNS yaitu sebanyak 8 orang $(7,7 \%)$. Sebagian besar responden mengalami smartphone addiction sangat rendah, yaitu sebanyak 48 responden (46,2\%). Terdapat 6 responden $(5,8 \%)$ dengan tingkat smartphone addiction tinggi. 
Sebagian besar responden memiliki peran yang sangat baik dalam menjalankan fungsi keluarga yaitu sebanyak 74 responden $(71,2 \%)$. Sebanyak 28 responden $(26,9 \%)$ menjalankan peran ibu dalam kategori baik dan 2 responden $(1,9 \%)$ menjalankan peran ibu dalam kategori cukup.

\section{Smartphone Addiction}

Smartphone adalah telepon genggam yang memiliki sistem operasi untuk masyarakat luas, dimana pengguna dapat menambahkan atau mengubah aplikasi sesuai keinginannya. Smartphone juga dapat diartikan sebagai telepon genggam yang menyerupai komputer mini yang memiliki kapasitas sama dengan sebuah telepon (Shiraisihietal, 2010).

Berbagai fitur dan aplikasi yang ada di dalam smartphone semakin membuat para pengguna lebih mudah untuk mengakses apapun yang diinginkan. Keunggulan ini membuat banyak orang menjadi semakin tergantung dengan smartphone, bahkan orang lebih memilih ketinggalan dompet dibandingkan ketinggalan martphone mereka (Zulaeha, 2011). Kebutuhan akan informasi dam gaya hidup pada masyarakat modern menjadi faktor pendukung penggunaan smartphone (Prayudi, 2014).

Berdasarkan tabel 1, menunjukkan bahwa mayoritas responden memiliki tingkat smartphone addiction yang sangat rendah, namun ada 6 responden yang tingkat smartphone addiction nya tinggi. Lima dari enam ibu dengan smartphone addiction tinggi merupakan ibu yang bekerja. Hal ini sesuai dengan salah satu fungsi smartphone yaitu fitur-fitur dalam smartphone dapat menunjang pekerjaan (Prayudi, 2014). Pesatnya arus globalisasi dan modernisasi menuntut para ibu bekerja tetap melakukan pekerjaannya, bahkan saat tidak dikantor. Fitur-fitur yang mendukung pekerjaan mereka seperti email, browser, pengatur jadwal, pdf reader, MS. word reader, dan aplikasi dalam komputer lain telah dapat diakses dari smartphone. Ibu dengan tingkat smartphone tinggi lainnya dalam penelitian ini merupakan ibu rumah tangga. Kaum ibu tidak kalah aktif dalam memanfaatkan internet dan berseluncur di jejaring sosial. Berdasarkan survei pada tahun 2014 yang dilakukan Marketers dan MarkPlus Insight di 10 kota urban di Indonesia, sekitar 5,4 juta netizen atau orang yang menghabiskan waktu tiga jam per hari menggunakan internet merupakan ibu rumah tangga dari total 32 juta netizen. Dalam survei Asian Digital Mum yang dirilis theAsianparent.com. dan dilakukan terhadap 10.000 calon ibu dan ibu yang memiliki anak berusia di bawah 16 tahun di empat negara, yaitu Singapura, Malaysia, Thailand dan Indonesia menunjukkan bahwa perempuan lebih sering menggunakan internet setelah menjadi ibu (Arindita, 2017). Sekitar 80 persen perempuan di Asia menggunakan internet setelah mereka menjadi ibu dan di saat yang sama 58 persen dari mereka mengurangi jam menonton televisi. Sejumlah 99 persen dari mereka menggunakan smartphone untuk mengakses internet. Sementara itu berdasarkan riset yang dilakukan oleh Universitas Padjadjaran, kegiatan yang paling sering dilakukan para ibu saat berseluncur di internet di antaranya belanja secara online, mencari referensi tentang pengasuhan dan tumbuh kembang anak serta berkomunikasi dengan teman-teman di 
jejaring sosial (Unpad.ac.id, 24 Maret 2017). Hal ini sesuai dengan gambar 1 , dimana tiga aplikasi teratas yang digunakan ibu merupakan media jejaring sosial yaitu whatsapp, facebook, dan instagram.

\section{Gambar 1. Persentase Penggunaan Aplikasi Smartphone oleh Responden}

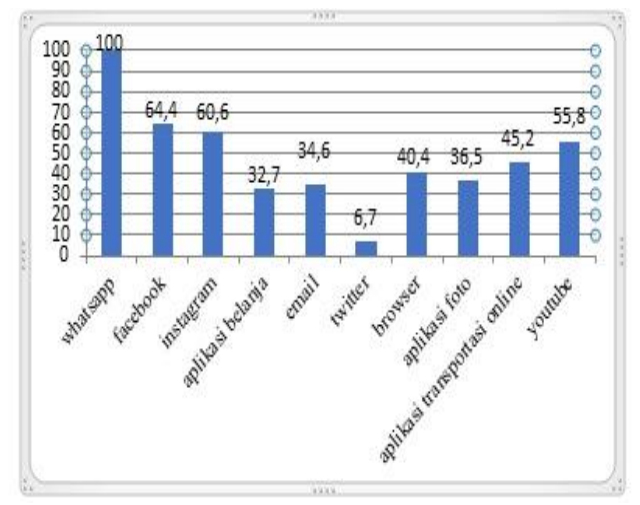

Berdasarkan data terbaru yang dirilis oleh Asosiasi Penyedia Jasa Internet Indonesia (APJII) pada tahun 2016, kelompok Ibu Rumah Tangga merupakan kelompok kedua terbesar yang menjadi pengguna internet (apjii.or.id, 5 November 2016).

\section{Peran Ibu}

Mayoritas Ibu dalam penelitian ini telah menjalankan perannya dalam fungsi keluarga dengan sangat baik $(71,2 \%)$. Dalam penelitian ini, ada 5 peran yang diukur yaitu peran dalam fungsi biologis, psikologis, sosialisasi, ekonomi, dan pendidikan. Peran dengan nilai terendah diantara lima fungsi tersebut adalah peran dalam fungsi ekonomi. Mayoritas responden dalam penelitian ini merupakan ibu rumah tangga, sehingga penghasilan utama hanya dari penghasilan suami. Ibu yang bekerja akan memiliki penghasilan sendiri, sehingga dapat membantu memenuhi kebutuhan keluarga. Hal ini sesuai dengan hasil penelitian Salaa (2015) yang menyatakan bahwa pada ibu yang bekerja terjadi peningkatan pendapatan keluarga. Sistem kebudayaan patrilineal menjadi penyebab rendahnya partisipasi perempuan dalam aktivitas ekonomi. Peran istri dianggap lebih rendah daripada pria, sehingga dominasi pria lebih kuat dalam aktivitas ekonomi (Djabu, et al, 2013).

Mayoritas ibu dalam penelitian ini menjalankan perannya dengan sangat baik, namun ada dua ibu yang menjalankan perannya dalam kategori cukup. Dua ibu dengan kategori cukup merupakan ibu bekerja, namun banyak juga ibu yang bekerja dapat menjalankan perannya dengan sangat baik. Penelitian ini tidak meneliti lebih jauh tentang status pekerjaan ibu dengan peran ibu menjalankan fungsi keluarga, namun dari penelitian Salaa J (2015) menyatakan bahwa Peran ibu rumah tangga yang bekerja di luar sebagai sebagai pencari nafkah ternyata tidak pernah meninggalkan tugas dan tanggung-jawabnya sebagai seorang isteri dan sebagai seorang ibu dalam keluarganya. Penelitian Arfina dan Nurhamlin (2014) juga menyatakan bahwa walaupun memiliki peran ganda, ibu rumah tangga juga mampu menjalankan fungsi keluarga dengan baik.

Selain dalam fungsi ekonomi, ibu juga berperan dalam fungsi pendidikan, sosialiasi, dan psikologi. Hal ini terlihat jelas dalam pengasuhan anak. Banyak penelitian yang mengangkat tema tentang peran ibu, seperti penelitian Werdinigsih dan Astarani (2012). Penelitian ini menyatakan bahwa peran ibu dalam pemenuhan kebutuhan dasar berhubungan dengan perkembangan 
motorik halus, perkembangan motorik kasar, dan perkembangan sosial anak.

\section{Hubungan Smartphone Addiction dengan Peran Ibu dalam Menjalankan Fungsi Keluarga}

Tabel 2. Crosstab Smartphone Addiction dengan Peran Ibu dalam Menjalankan Fungsi Keluarga

\begin{tabular}{|c|c|c|c|c|c|c|c|c|c|c|c|c|}
\hline VARIABEL & \multicolumn{12}{|c|}{ Peran Ibu } \\
\hline Kategori & & agat & & Irang & & Culaup & & aik & & gat Baik & & \\
\hline Smartohone Addiction & $\mathrm{N}$ & $\%$ & $\mathrm{~N}$ & $\%$ & $\mathrm{~N}$ & $\%$ & $\mathrm{~N}$ & $\%$ & $\mathrm{~N}$ & $\%$ & $\mathrm{~N}$ & $\%$ \\
\hline Sangat Rendah & 0 & 0 & 0 & 0 & 0 & 0 & 6 & 12,5 & 42 & 87,5 & 48 & 100 \\
\hline Rendah & 0 & 0 & 0 & 0 & 0 & 0 & 15 & 40,5 & 22 & 59,5 & 37 & 100 \\
\hline Sedang & 0 & 0 & 0 & 0 & 0 & 0 & 4 & 30,8 & 9 & 69,2 & 13 & 100 \\
\hline Tinggi & 0 & 0 & 0 & 0 & 2 & 33,3 & 3 & 50 & 1 & 16,7 & 6 & 100 \\
\hline Sangat Tinggi & 0 & 0 & 0 & 0 & 0 & 0 & 0 & 0 & 0 & 0 & 0 & 100 \\
\hline TOTAL & 0 & 0 & 0 & 0 & 2 & 1,9 & 28 & 26,9 & 74 & 71.2 & 104 & 100 \\
\hline
\end{tabular}

Tabel 3. Hasil Uji Korelasi dengan Spearman Rank

\begin{tabular}{lc}
\hline \multicolumn{1}{c}{ Item } & Nilai \\
\hline Signifikansi $(p)$ & 0,000 \\
Koefisien korelasi Spearman Rank $(r)$ & $-0,360$ \\
\hline
\end{tabular}

Hasil analisis korelasi dengan Spearman rank menunjukkan bahwa ada hubungan yang signifikan (berarti) antara smartphone addiction dengan peran ibu dalam menjalankan fungsi keluarga. Angka koefisien korelasi yang bernilai negatif menunjukkan bahwa arah hubungan kedua variabel bersifat berlawanan, artinya semakin tinggi tingkat smartphone addiction maka semakin kurang peran ibu dalam menjalankan fungsi keluarga. Angka koefisien korelasi sebesar 0,360 berarti tingkat kekuatan hubungan antara smartphone addiction dengan peran ibu dalam menjalankan fungsi keluarga adalah cukup kuat.

Smartphone dapat memberikan dampak positif dan negatif tergantung bagaimana seseorang menggunakannya.
Smartphone dalam pengasuhan anak, dapat digunakan sebagai sarana hiburan keluarga, sumber dukungan sosial, atau akses materi pendidikan untuk anakanak (Redesky et al., 2013). Namun, penggunaan smartphone juga dapat mengalihkan perhatian ibu saat berinteraksi dengan anak, dimana interaksi ini sangat penting bagi perkembangan kognitif, bahasa, dan emosional anak (Glascoe \& Leew, 2010). Penelitian terbaru dari Boston Medical Center dalam studi observasionalnya terhadap 55 orang tua, menunjukkan bahwa orang tua yang sudah terfokus terhadap e-mail, games, atau aplikasi lain pada smartphone-nya memiliki interaksi negatif terhadap anak mereka, dan membuat anak mereka merasa seperti berebut perhatian dengan smartphone orang tuanya (Redesky et al., 2013). Banyak kritik di media massa tentang penggunaan smartphone di waktu pengasuhan anak karena dapat menganggu keselamatan dan emosi anak (Salam, 2013). Hasil penelitian Nuzlia, dkk (2015) menunjukkan bahwa intensitas penggunaan smartphone oleh ibu berhubungan dengan interaksi ibu dan anak. Penelitian tersebut juga menyimpulkan bahwa terdapat pengaruh langsung dan tidak langsung intensitas penggunaan smartphone oleh ibu terhadap hasil deteksi dini perkembangan sosial emosional anak yang diperantarai oleh interaksi ibu dan anak. Hal ini menunjukkan bahwa penggunaan smartphone dapat menganggu interaksi ibu dan anak yang dapat menyebabkan terganggunya juga pemenuhan peran ibu dalam menjalankan fungsi pendidikan, psikologi, biologis, dan sosialisasi.

Smartphone tidak hanya mengganggu interaksi antara ibu dan anak, namun juga ibu dengan suami dan 
dengan orang lain. Hal ini sesuai dengan penelitian Muflih, Hamzah, \& Puniawan (2017) yang menyatakan bahwa ada hubungan yang signifikan antara tingkat ketergantungan smartphone dengan interaksi sosial. Penelitian Kamil (2016) juga menyebutkan bahwa penggunaan gadget seperti smartphone berdampak kepada kurangnya komunikasi tatap muka dalam kehidupan sehari-hari. Kurangnya komunikasi ini juga dapat memberikan dampak dalam hubungan suami istri. Seperti yang disebutkan dalam penelitian Costa (2017) yang menyatakan bahwa terdapat hubungan yang positif antara komunikasi suamiistri dengan manajemen konflik dalam keluarga, dimana manajemen konflik ini mempengaruhi keutuhan rumah tangga. Pendapat lain juga mengatakan bahwa penggunaan internet seperti dalam smartphone secara tidak langsung dapat menyebabkan stress pada ibu yang dapat mempengaruhi kualitas perkawinan dan fungsi keluarga (McDaniel, Coyne, dan Holmes, 2012).

\section{DAFTAR PUSTAKA}

Afrina, M., \& Nurhamlin. (2014). Peran Ibu Rumah Tangga dalam Membantu Perekonomian Keluarga. Jurnal Online Mahasiswa (JOM) Bidang Ilmu Sosial dan Ilmu Politik, 1(1).

Aipji.or.id. (5 November 2016). Buletin AIPJI Edisi 05 November 2016. Diakses pada 3 Desember 2018 dari https://apjii.or.id/downfile/file/BUL ETINAPJIIEDISI05November2016. pdf

Arindita, Ruvira. 2017. Representasi Ibu Ideal pada Media Sosial (Analisis Multimodality pada Akun Instagram @ andienippekawa). Jurnal Komunikasi Global, Volume 6, Nomor 2, 2017 : 131-147
Attamimi, A. (2011). The reasons for the prevalence of Blackberry cellphones and the resulting educational effects from the perspective of secondary school students in Abo-Dhabi. Conference on the negative effects of cellphones on secondary school students. UAE, 105-130.

Bian, M. \& Leung, L. (2014). Smartphone addiction: linking loneliness, shyness, symptoms and patterns of use to social capital. Media Asia, 2, 159-176.

Costa, TCSD. 2017. Hubungan Antara Komunikasi Suami-Istri Dengan Manajemen Konflik Khususnya Pada Pasangan Suami-Istri Yang Tinggal Di Lingkungan Asrama Brimob Polda NTT. SKRIPSI : Universitas Kristen Setya Wacana

Dildar, S., Sitwat, A., \& Yasin, S. (2013). Intimate Enemies: Marital Conflicts and Conflict Resolution Styles in Dissatisfied Married Couple. Middle-East Journal of Scientific Research,15, 1433-1439.

Djabu, O., Goni, J. H., \& Tumiwa, J. (2013). Peranan Ibu Rumah Tangga yang Bekerja dalam Meningkatkan Status Sosial Keluarga di Kelurahan Teling Atas Kecamatan Wanea Kota Manado. Jurnal Acta Diurna, 2(3).

Glascoe FP1, Leew S. 2010. Parenting Behaviors, Perceptions, And Psychosocial Risk: Impacts On Young Children's Development.Pediatrics Journal : February 2010, Volume 125/Issue 2. http://pediatrics.aappublications.org/ content/pediatrics/125/2/313.full.pdf

Hong, F., Chiu, S. \& Huang, D. (2012). A model of the relationship between psychological characteristics, mobile phone addiction and use of mobile phones by taiwanese university female students. Computers in Human Behavior, 28, 
2152-

2159.http://dx.doi.org/10.1016/j.chb .2012.06.020

Kamil, MF. 2016. Pengaruh Gadget Berdampak kepada Kurangnya Komunikasi Tatap Muka dalam Kehidupan Sehari-Hari. SKRIPSI. IAIN Raden Intan Lampung

McDaniel BT, Coyne SM, Holmens EK. 2012. New Mothers And Media Use: Associations Between Blogging, Social Networking, And Maternal Well-Being. Maternal and Child Health Journal : Vol.16, issue 7, pp 1509-1517

Muflih M, Hamzah, Purniawan Y. 2017. Students' Use Of Smartphones and Social Interaction in SMAN I Kalasan Sleman Yogyakarta. Idea Nursing Journal : Vol. VIIII No.1, 2017

Nurpratiwi, A. 2010. Pengaruh Kematangan Emosi dan Usia Saat Menikah Terhadap Kepuasan Pernikahan pada Dewasa Awal. Skripsi. Jakarta. UIN Syarif Hidayatullah.

Nuzlia FL, Haryanti F, Wahyuni, B, Gamayanti IL. 2015. Hubungan antara Intensitas Penggunaan Smartphone oleh Ibu terhadap Hasil Deteksi Dini Perkembangan SosialEmosional Anak Pra Sekolah di Kota Yogyakarta. SKRIPSI. Universitas gajah Mada

Prayudi, S. 2014. Fenomena Penggunaan Smartphone di kalangan Pelajar (Studi Kasus di SMP Islam Athirah 1 Makassar). SKRIPSI. Universitas Hasannudin

Rahmiati, A. (2010). Pengaruh Emotional Expressivity Pasangan Suami-Istri Terhadap Kepuasan Pernikahan. Skripsi. Jakarta. UIN Syarif Hidayatullah
Rapid Value Solution. (2014). Internet, Smartphone \& Social Media Usage Statistic. Diakses Agustus, 19, 2018 dari

http://www.rapidvaluesolutions.com /wpcontent/uploads/2014/11/Interne t-Smartphoneand-Social-MediaUsageStatistics-by-RapidValue$\underline{\text { Solutions.pdf }}$

Redesky, J.S., Kistin, C.J., Zuckerman, B., Nitzberg, K., Gross, J., KaplanSanoff, M., Augustyn, M. \& Silverstein, M. (2014). Patterns of Mobile Device Use by Caregivers and Children During Meals in Fast Food Restaurans. Pediatrics Vol 133

Salaa, Jeiske. 2015. Peran Ganda Ibu Rumah Tangga dalam Meningkatkan Ekonomi Keluarga di Desa Tarohan Kecamatan Beo Kepulauan Talaud. Jurnal Holistik Tahun VIII No. 15 / Januari - Juni 2015.

Salehan, M. \& Neghaban A. (2013). Social networking on smartphone: while mobile phone become addictive. Journal: Computers in Human Behavior, 34, 2632-2639.

Shirasihietal. 2010. Perbedaan Tajam Penglihatan antara Pengguna Telepon Pintar dengan yang Tidak Menggunakan Telepon Pintar pada Siswa SMA. St. Thomas 1 Medan. SKRIPSI. Universitas Sumatera Utara.

Unpad.ac.id. 24 Maret 2017. Indonesia Masih digunakan untuk Media Sosial. Diakses pada 3 Desember 2018 dari http://www.unpad.ac.id/2017/03/inte rnet-indonesia-masih-digunakanuntuk-media-sosial/

Werdiningsih ATA, Astarani K. 2012. Peran Ibu dalam Pemenuhan Kebutuhan Dasar Anak terhadap Perkembangan Anak Usia Prasekolah. Jurnal STIKES. Volume 5. No. 1, Juli 2012. 
Zulaeha. 2011. Preferensi terhadap Merk pada Konsumen dalam Pembelian Smartphone (Penelitian terhadap Konsumen Pengguna Apple Iphone, RIM, Blackberry, dan Smartphone Berbasis Google Android). SKRIPSI. Universitas Indonesia. 